\title{
Case report: Treatment of Facial Nerve Palsy Following Bilateral Sagittal Split Ramus Osteotomy
}

\author{
Ji-won Ryu, D.D.S.,M.S.D. \\ Department of Oral medicine, School of Dentistry, Chosun University
}

\begin{abstract}
Bilateral sagittal split ramus osteotomy(BSSRO) of the mandible is an essential and commonly used procedure to correct dentofacial deformities and malocclusion. The possible complications associated with BSSRO include inferior alveolar nerve injury, bleeding, temporomandibular disorder, unfavorable fractures, and clinical relapse. The incidence of facial nerve palsy after orthognathic surgery recently reported is $0.1 \%$. The probable etiologies have included facial nerve compression, complete or incomplete nerve transection, nerve traction, and nerve ischemia from anesthetic injection. Postoperative facial palsy is one of the most serious complications because it reduces the quality of life and significantly reduces social interaction. The case of a 24-year-old patient who underwent bilateral sagittal split ramus osteotomy is described. The medical records and postoperative photographs were reviewed in detail to collect information on the clinical course, treatment, and outcomes.
\end{abstract}

Key words : Bilateral sagittal split ramus osteotomy, Facial nerve palsy, Orthognathic surgery

\section{INTRODUCTION}

Bilateral sagittal split ramus osteotomy(BSSRO) of the mandible is an essential and commonly used procedure to correct dentofacial deformities and malocclusion. The possible complications associated with BSSRO include inferior alveolar nerve injury, bleeding, temporomandibular disorder, unfavorable fractures, and clinical relapse. ${ }^{1)}$ The incidence of

\section{Corresponding author : Ji-Won Ryu}

Associate Professor, Department of Oral Medicine,

Chosun University 421, School of Dentisty

Seosuk-dong Dong-Gu, Gwang-Ju, 501-825

Tel: 062-220-3897

Fax: 062-234-2119

E-mail: dentian@chosun.ac.kr

Received: 2013-07-15

Accepted: 2013-08-06

* This study was supported by research funds from Chosun University, 2011 facial nerve palsy after orthognathic surgery recently reported is $0.1 \%{ }^{2)}$ The probable etiologies have included facial nerve compression, complete or incomplete nerve transection, nerve traction, and nerve ischemia from anesthetic injection. ${ }^{3,4)}$ Postoperative facial palsy is one of the most serious complications because it reduces the quality of life and significantly reduces social interaction. ${ }^{5)}$ The case of a 24-year-old patient who underwent bilateral sagittal split ramus osteotomy is described. The medical records and postoperative photographs were reviewed in detail to collect information on the clinical course, treatment, and outcomes.

\section{П. CASE}

A healthy 24-year-old man with prognathism underwent a bilateral sagittal split ramus osteotomy(BSSRO). Orthodontic treatment had been given for 12 months, and orthognathic surgery 
involved a BSSRO to set back the mandible $18 \mathrm{~mm}$, on both sides. The intraoperative course was uneventful and ice packs were applied during the first 24 hours postoperatively. Three days after the operation, severe facial swelling was noted, and left facial palsy was detected by an oral and maxillofacial surgeon. So, the patient was referred to the Department of Oral Medicine. The patient was unable to wrinkle his forehead, close the left eye or smile symmetrically.(Fig. 1.) Taste functions were normal. He had no signs of viral(herpetic) infection. An orthopantomogram(Panorama) and lateral cephalogram were performed. In these radiographic examination, there were no unfavorable splits or fracture of the condylar region.

The patient was given steroid therapy(prednisone 10mg 3 times daily for 2 weeks and thereafter a tapering dose for 1 weeks) for 1 month and physical therapy with electrical stimulation(transcutaneous electrical nerve stimulator:TENS), and active exercise of the facial muscles. An eye patch, ointment for the left eye, and lubrication were prescribed by an opthalmologist. After 1 month, his smile was symmetrical but there was mild restoration of tonus to the left periorbital region.(Fig. 2.) The patient complained of the pain from slight touch and numbness in the affected area. Neurosensory mapping in the affected area showed no definite region. To alleviate the symptoms, gabapentin(Neurontin ${ }^{\circledR}$ ) was prescribed. The starting dosage was $600 \mathrm{mg} /$ day (200mg 3 times for 2 weeks) and thereafter increasing $900 \mathrm{mg} /$ day for 2 weeks. Two months follow-up visit, a complete recovery of all left-sided facial muscle movement was seen without residual asymmetry,(Fig. 3.) and there was no pain in the affected area, so the gabapentin prescription was stopped.

\section{DISCUSSION}

Sagittal split ramus osteotomy(SSRO) of the mandible introduced by Trauner and Obwegeser in $1957^{6}$ ), is an essential and frequently used operative technique in orthognathic surgery. ${ }^{2)}$ Many articles have been published about its complications, the most common problem is neurosensory disturbance of the inferior alveolar nerve(IAN). ${ }^{7)}$ Injury to the facial nerve following intraoral SSRO is a rare complication, but facial palsy is a serious complication that can result from the procedure. Dendy was the first to comment on the possible etiologic basis for a facial nerve injury after SSRO."

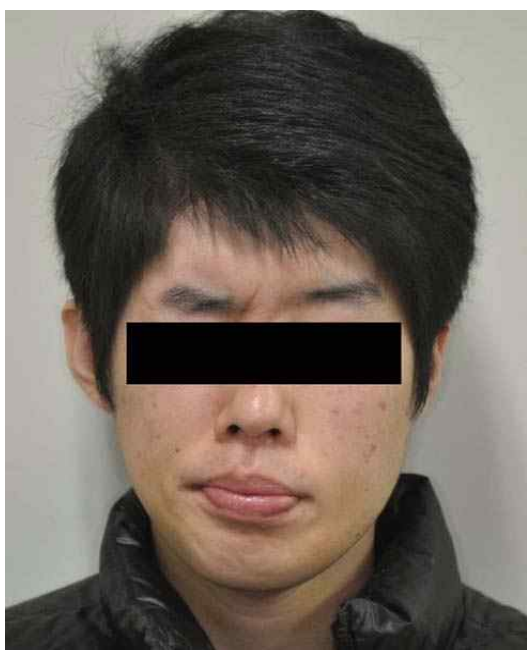

A. Closing eyes

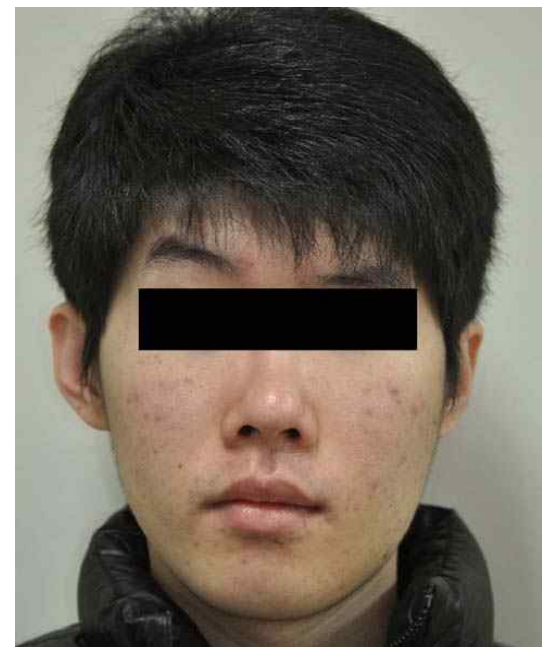

B. Raising eyebrows

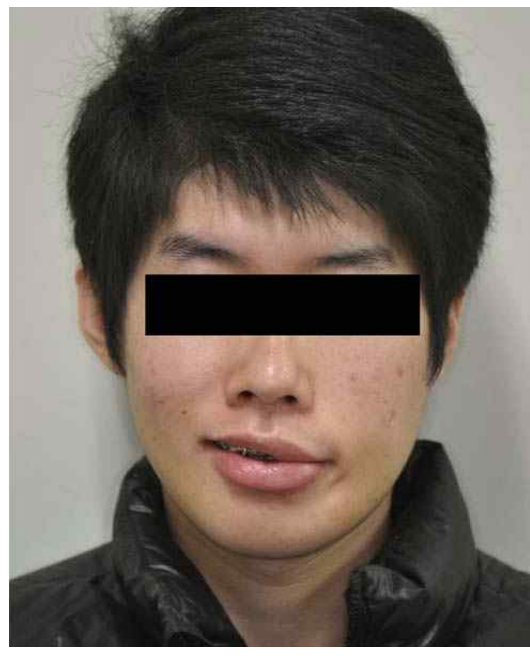

C. Smile

Fig. 1. Photographs of the patient at first visit 


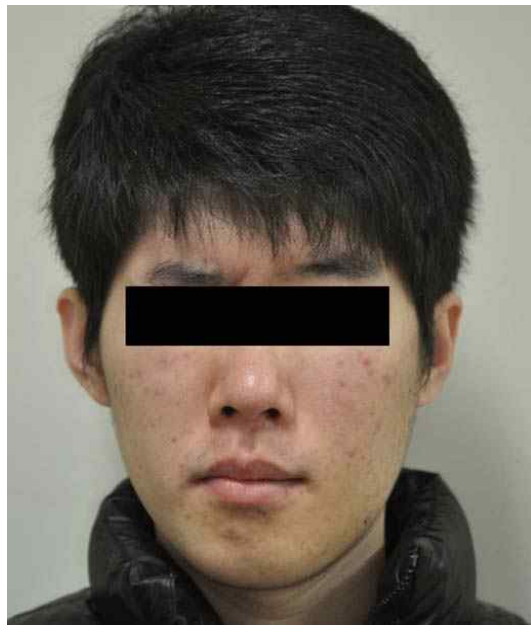

A. Closing eyes

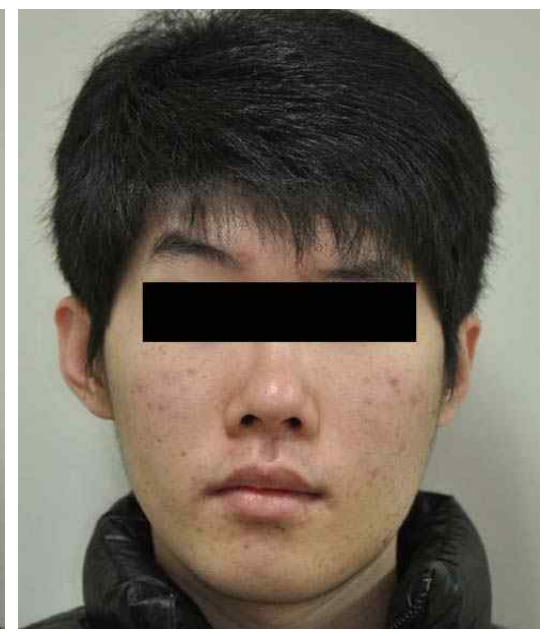

B. Raising eyebrows

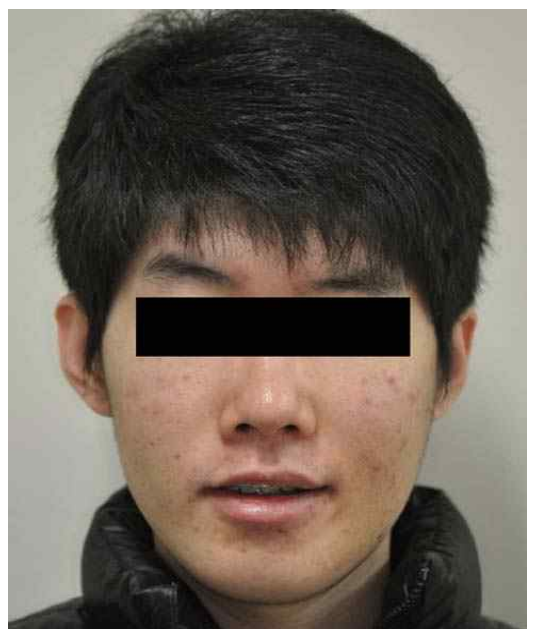

C. Smile

Fig. 2. Photographs of the patient after 1 months

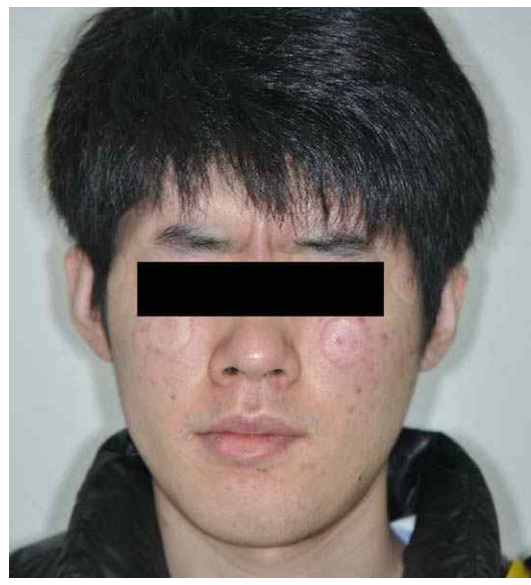

A. Closing eyes

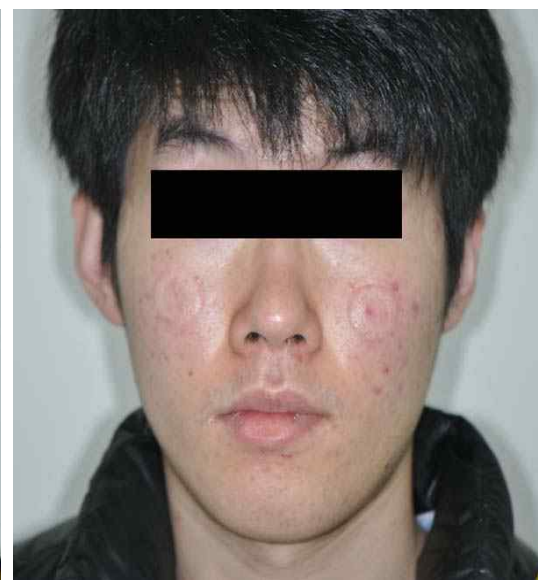

B. Raising eyebrows

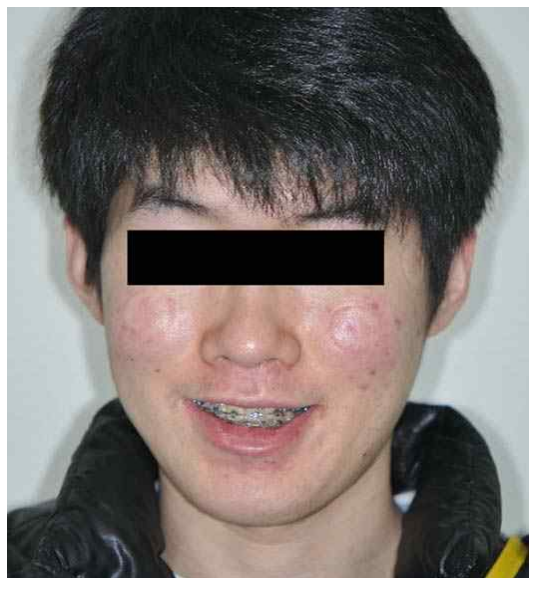

C. Smile

Fig. 3. Photographs of the patient after 2 months

The possible mechanisms to induce the facial nerve damage were: 1) compression against the mastoid process during the introduction of retractors, 2) fracture of the styloid process, 3) postoperative facial edema." Choi stated that the relationship between the posterior border of the mandibular ramus and the facial nerve is close. ${ }^{2}$ In the open-mouth position adopted for the SSRO procedure, the distance between the posterior border of the mandibular ramus and the facial nerve becomes even closer and is usually less than $1 \mathrm{~cm}^{8)}$
Therefore, facial palsy after SSRO could be caused by compression, traction, or even transection of the facial nerve by the adjacent bony structures or instrumentation. ${ }^{8)}$

Injury to the facial nerve during SSRO of the mandible can involve either the main trunk or more selective branches of the facial nerve, depending on the mechanism of injury. ${ }^{9)}$ An injury to the facial nerve could potentially range from a first to a fifth degree injury in the Sunderland system. ${ }^{10)}$ If a facial nerve palsy is not present immediately after surgery, 
the nerve is still in continuity and surgical exploration is not indicated. In this case, the facial nerve palsy appeared after 3 days of surgery, so the clinician decided to give conservative treatment. At the onset of facial palsy, it is important to differentiate the type of facial palsy. ${ }^{6}$ In this case, the patient had no symptoms of taste problem, so central nerve damage was ruled out. According to the House-Brackman facial nerve grading system, ${ }^{11)}$ the reported case was graded as level IV, moderately severe dysfunction, with complete recovery expected.

Treatment started with steroid medication. The main purpose of steroid medication is to reduce postoperative edema. ${ }^{6}$ Timing of initiation of steroid therapy has an important role to play in enhancing nerve regeneration. ${ }^{12)}$ Short term steroid medications inhibit the inflammatory response and, consequently the recruitment of macrophages. However, long-term steroid medication will delay nerve regeneration because of a steroid dependent decrease in the number of macrophages. ${ }^{6)}$ In this case, steroids(prednisone) were given for 1 month, so prolonged steroid medication could have been harmful to the condition of the patient, so another treatment modality was tried. Combined therapies with steroid medication were electrical stimulation and instruction of active exercise of the facial muscles. It was proposed that electrical stimulation might enhance axonal regeneration and maintain the normal motor unit characteristic. ${ }^{6)}$

The peculiarity of this case report was the prescription of gabapentin $\left(\right.$ Neurontin $\left.{ }^{\circledR}\right)$. Gabapentin is an anti-epileptic agent but now it is also recommended as a first-line drug in neuropathic pain. $^{13)}$

In this case, gabapentin was prescribed for reducing the pain with mechanical stimulus (allodynia) and numbess. The systemic administration of gabapentin has been shown to increase the paw withdrawal latency and produce anti-allodynic effects in a mice model of partial sciatic nerve ligation of neuropathic pain in a dose dependent manner. ${ }^{14)}$ There have been a number of clinical studies documenting the beneficial effects of gabapentin in different types of neuropathic pain like neuropathy due to; cancer, HIV infection, diabetic neuropathy, trigeminal neuralgia and post-operative neuropathic pain. ${ }^{13)}$ a $2 \delta$ subunit of the voltage gated calcium channels on the DRG neurons has been defined as the main molecular target for gabapentin and amongst the different types of $a 2 \delta$, $a 2 \delta^{-1}$ has been the key binding target of gabapentin. ${ }^{15)}$ a $2 \delta-1$ is the extracellular auxillary subunit of voltage gated calcium channels particularly the $\mathrm{N}^{-}$and L-types, but not the $\mathrm{T}$ - types. ${ }^{16)}$

There were no scientific articles found that the effect of gabapentin for treatment of facial palsy. But there is an interesting article that nimodipine, L-type $\mathrm{Ca}^{2+}$-ion channel blocker, promotes regeneration of peripheral facial nerve function after traumatic injury following maxillofacial surgery. ${ }^{17)}$ In this case, complete recovery of facial nerve was achieved in 2 months. The time of spontaneous facial nerve recovery after BSSRO is reported from $4^{3)}$ to $9^{18)}$ months. In this case, the time to recover the function of facial nerve was shorter than the reported results. Even though there has been no published data about promoting regeneration of facial nerve with gabapentin and this is a single patient case report, gabapentin might be helpful to improve facial nerve function. Further investigation should be taken to prove this hypothesis.

Considering the quality of life of patients, it is very important to prevent facial nerve palsy. Careful dissection, retraction and precise osteotomy are needed for protection of the facial nerve. ${ }^{19)}$ If nerve damage is observed, accurate diagnosis and early management can help in the recovery of the facial nerve function and esthetics.

\section{REFERENCES}

1. Kim SG, Park SS. Incidence of complications and problems related to orthognathic surgery. J Oral Maxillofac Surg 2007;65(12):2438-2444.

2. Choi BK, Goh RC, Chen PK, Chuang DC, Lo LJ, Chen YR. Facial nerve palsy after sagittal split ramus osteotomy of the mandible: mechanism and outcomes. 
J Oral Maxillofac Surg 2010;68(7):1615-1621.

3. Dendy RA. Facial nerve paralysis following sagittal split mandibular osteotomy: A case report. Br J Oral Surg 1973;11(2):101-105.

4. Cousin GC. Facial nerve palsy following intra-oral surgery performed with local anaesthesia. J R Coll Surg Edinb 2000;45(5):330-333.

5. Ruiz LP, Lara JC. Facial nerve palsy following bilateral sagittal split ramus osteotomy for setback of the mandible. Int J Oral Maxillofac Surg 2011;40 (8):884-886.

6. Rai KK, Shivakumar HR, Sonar MD. Transient facial nerve palsy following bilateral sagittal split ramus osteotomy for setback of the mandible: a review of incidence and management. J Oral Maxillofac Surg 2008;66(2):373-378.

7. de Santana Santos T, Albuquerque KM, Santos ME, Laureano Filho JR. Survey on complications of orthognathic surgery among oral and maxillofacial surgeons. J Craniofac Surg 2012;23(5):e423-430.

8. de Vries K, Devriese PP, Hovinga J, van den Akker HP. Facial palsy after sagittal split osteotomies. A survey of 1747 sagittal split osteotomies. J Craniomaxillofac Surg 1993;21(2):50-53.

9. Lanigan DT, Hohn FI. Facial nerve injuries after sagittal split mandibular ramus osteotomies for advancement: a report of 2 cases and review of the literature. J Oral Maxillofac Surg 2004;62(4):503-507.

10. Sunderland S. A classification of peripheral nerve injuries producing loss of function. Brain 1951;74 (4):491-516

11. House JW, Brackmann DE. Facial nerve grading system. Otolaryngol Head Neck Surg 1985;93:146147.
12. Al-Bishri A, Dahlin L, Sunzel B, Rosenquist J. Systemic betamethasone accelerates functional recovery after a crush injury to the rat sciatic nerve. J Oral Maxillofac Surg 2005;63(7):973-977.

13. Kukkar A, Bali A, Singh N, Jaggi AS. Implications and mechanism of action of gabapentin in neuropathic pain. Arch Pharm Res 2013;36(3):237-251.

14. Kusunose N, Koyanagi S, Hamamura $\mathrm{K}$ et al. Molecular basis for the dosing time-dependency of anti-allodynic effects of gabapentin in a mouse model of neuropathic pain. Mol Pain 2010;26;6:83.

15. Jaggi AS, Singh N. Role of different brain areas in peripheral nerve injury-induced neuropathic pain. Brain Res 2011;24;1381:187-201.

16. Davies A, Hendrich J, Van Minh AT, Wratten J, Douglas L, Dolphin AC. Functional biology of the alpha(2)delta subunits of voltage-gated calcium channels. Trends Pharmacol Sci 2007;28(5):220-228.

17. Scheller K, Scheller C. Nimodipine promotes regeneration of peripheral facial nerve function after traumatic injury following maxillofacial surgery: an off label pilot-study. J Craniomaxillofac Surg 2012;40(5):427-434.

18. Jain Y, Falcioni M, Agarwal M, Taibah A, Sanna M. Total facial paralysis after vestibular schwannoma surgery: probability of regaining normal function. Ann Otol Rhinol Laryngol 2004;113(9):706-710.

19. Jin SY, Kim SG, Kim HG et al. Facial nerve palsy after Bilateral Sagittal Split Ramus Osteotomy: Case report. J Korean Assoc Maxillofac Plast Reconstr Surg 2011;33(3):276-280. 
국문초록

\title{
증례보고 : 양측 하악지 시상골 절단술 후 발생한 안면신경 마비
}

\section{조선대학교 치의학전문대학원 구강내과학교실}

\author{
유 지 원
}

양측 하악지 시상 골절단술은 악안면 기형 및 부정교합을 치료하기 위해 흔히 사용되는 필수불가결한 술식이라고 할 수 있다. 하악지 시상 골절단술 후 발생할 수 있는 합병증으로는 하치조 신경 손상, 출혈, 측두하악장애, 부적절한 골면의 유합 및 골절, 재발 등이 있다. 악교정 수술 후 안면신경 마비의 발생 유병율은 최근 0.1 퍼센트로 보고되고 있다. 증상 발생의 원인으로는 안면신경의 압박, 신경의 불완전 또는 완전 손상, 신경의 견인, 마취제에 의한 신경의 허혈 등이 있다. 술 후 발생 된 안면 신경의 마비는 환자의 삶의 질을 저해하고 사회활동을 기피하게 함으로써 가장 심각한 합병증 중 하나라고 볼 수 있다. 본 증례에서는 양측 하악지 시상 골전달술을 시행 후 발생한 안면신경 마비에 대하여 보고하고 있다.

주제어: 악교정 수술, 안면신경 마비, 양측 하악지 시상 골절단술 